\title{
Rational pharmacological approaches for cognitive dysfunction and depression in Parkinson's disease
}

\section{Maritza Sandoval-Rincón ${ }^{1}$, Michel Sáenz-Farret ${ }^{1,2}$, Adán Miguel-Puga ${ }^{3}$, Federico Micheli ${ }^{2}$ and Oscar Arias-Carrión ${ }^{1,3}$ *}

1 Unidad de Trastornos del Movimiento y Sueño, Hospital General Ajusco Medio, Secretaría de Salud, Mexico City, Mexico

2 Programa de Parkinson y Movimientos Anormales, Hospital de Clínicas "José de San Martín," Universidad de Buenos Aires, Buenos Aires, Argentina

${ }^{3}$ Unidad de Trastornos del Movimiento y Sueño, Hospital General Dr. Manuel Gea González, Secretaría de Salud, Mexico City, Mexico

\section{Edited by:}

Jaime Kulisevsky, Hospital de la Santa Creu i Sant Pau, Spain

\section{Reviewed by:}

Graziella Madeo, Università degli

Studi di Roma Tor Vergata, Italy

Saul Martinez-Horta, Hospital de la

Santa Creu i Sant Pau, Spain

\section{*Correspondence:}

Oscar Arias-Carrión, Unidad de

Trastornos del Movimiento y Sueño,

Hospital General Dr. Manuel Gea

González/IFC-UNAM, Calzada de

Tlalpan 4800, Delegación Tlalpan,

Mexico City 14080, Mexico

e-mail:arias@ciencias.unam.mx
Parkinson's disease (PD) is not a single entity but rather a heterogeneous neurodegenerative disorder. The present study aims to conduct a critical systematic review of the literature to describe the main pharmacological strategies to treat cognitive dysfunction and major depressive disorder in PD patients. We performed a search of articles cited in PubMed from 2004 to 2014 using the following MeSH terms (Medical subject headings) "Parkinson disease"; "Delirium," "Dementia," "Amnestic," "Cognitive disorders," and "Parkinson disease"; " depression," "major depressive disorder," "drug therapy." We found a total of 71 studies related to pharmacological treatment in cognitive dysfunction and 279 studies for pharmacological treatment in major depressive disorder. After fulfillment of all the inclusion and exclusion criteria, 13 articles remained for cognitive dysfunction and 11 for major depressive disorder, which are presented and discussed in this study. Further research into non-motor symptoms of PD may provide insights into mechanisms of neurodegeneration, and provide better quality of life by using rational drugs.

Keywords: Parkinson's disease, cognitive disorders, depression, major depressive disorder, dementia, drug therapy, non-motor symptoms

\section{INTRODUCTION}

Parkinson disease $(\mathrm{PD})$ is one of the most complex neurodegenerative diseases with a broad spectrum of motor and non-motor symptoms (1). According to the United Kingdom Parkinson Disease Society Brain Bank, the clinical diagnosis is based on the presence of two or three motor features: bradykinesia plus rigidity or tremor at rest (or both). However, these criteria neither separate PD from the many other forms of parkinsonism nor contemplates the non-motor signs. Despite intense research, no effective therapy is currently available to prevent the onset, or to halt the progression of the disease.

In PD patients, there is a spectrum of cognitive dysfunction, ranging from mild cognitive impairment (PD-MCI) to $\mathrm{PD}$ dementia [PDD; (2)]. PD-MCI may represent the earliest stage of cognitive decline and a risk factor for developing PDD (3). Even when it is considered to be common, frequency estimates may vary between studies due to many factors such as differences in the populations studied (e.g., clinic or community-based; incident or prevalent of PD), clinical and neuropsychological criteria used, and the number and type of neuropsychological tests assessed (4). A comprehensive review of the literature on PD and cognitive impairment conducted by the movement disorder society (MDS) task force on PD-MCI demonstrated a mean cross-sectional prevalence rate of $26.7 \%$ (range 18.9-38.2\%) in non-demented patients (5) and its association with the subsequent development of PDD (3). The clinical profile of PD-MCI is heterogeneous, with a broad spectrum of clinical deficits and severity affecting both non-amnestic and amnestic domains, such as executive function, psychomotor speed, visuospatial abilities, language, and memory. Overall, non-amnestic single-domain impairment is the most affected (4).

Previous studies indicated that executive deficits were more important predictors of subsequent cognitive decline $(6,7)$. More recently, authors of The CamPaIGN study reported a 10-year follow up in patients with PD; they found that a poorer baseline performance on tests with a posterior cortical basis resulted in an increased risk for dementia, which leaded to the distinction of two cognitive syndromes in PD: a "frontal executive" cognitive deficit, primarily due to dysfunction in dopaminergic frontostriatal networks; and a "posterior cortical" cognitive deficit due to dysfunction in non-dopaminergic systems, which were related to the development of dementia and characterized by deficits on semantic fluency and pentagon copying (8). One study supported by functional imaging, which have reported that patients with PDD presented with a severe cortical cholinergic deficit in comparison to non-demented PD patients, indicates that the acetylcholine system is the non-dopaminergic system related to the posterior cortical subtype and to the progression to dementia (9).

This diverse profile in MCI-PD (evident even in early phases) characterizes the clinical heterogeneity of cognitive impairment and its risk for subsequent dementia, being the most affected, the executive, mnemonic, and visuospatial domains $(6,10,11)$.

Another systematic review showed that the prevalence of dementia among PD subjects, which included a total number of 1767 PD patients, 554 of them with dementia, was of $24.5 \%$ (95\% confidence interval $17.4-31.5 \%$; (12). The clinical profile 
of PDD includes impairment of the attention, memory, language, visuospatial function, construction, praxis, and executive function domains. There are some phenomenological differences between PDD and Alzheimer dementia (AD), particularly in executive functions, so that a "subcortical" or "dysexecutive" pattern predominates in PDD. However, these differences are difficult to identify in the late stages of dementia (13). Neuropathological studies, therefore, revealed that cortical Lewy body/neuritic pathology is more extensive and severe in PDD than in PD without dementia (14). Also, cholinergic deficits occur in PDD, with higher levels in those with a longer duration of parkinsonism prior to dementia with lower cortical and limbic Lewy body/neuritic burden (15), and are ascribed to neuronal loss in basal forebrain cholinergic nuclei $(15,16)$. The presence of cortical cholinergic deficit in patients with PDD suggests that treatment with cholinesterase inhibitors may be beneficial (17).

Given the chronic and debilitating nature of PD, it is not surprising that many patients suffer negative emotional consequences, particularly depression. Other psychiatric symptoms in PD include sleep disorders, cognitive impairment, psychosis, and anxiety (18). Reported rates of major depressive disorder in PD patients vary widely, ranging from 7 to $76 \%$ (18). Few scales like the Beck depression inventory (BDI) and the Geriatric Depression Scale of Yesavage (GDS) have been validated for the screening of depression in PD patients, or to assess the severity of it, which is the case of the Hamilton rating scale for depression (HAMD) and the Montgomery-Asberg depression rating scale [MADRS; (19)]. The etiology of depression in PD is thought to be an interaction of exogenous causes (e.g., the fact of being diagnosed with a disabling, chronic disease for which there is no known cure) and endogenous causes (e.g., dopamine deficiency) (20). As the quality of life (QoL) in PD patients can be affected by psychiatric symptoms, treatment for major depressive disorder in $\mathrm{PD}$ is clinically relevant (21).

Cognitive dysfunction and major depressive disorder are both recognized entities that can appear simultaneously in any step of neurodegeneration in PD. Up to day, there are no recommendations for the optimal treatment for any of these comorbidities of PD. Here, we evaluate available evidence from clinical studies to identify the efficacy and safety of available pharmacological options to treat cognitive dysfunction and major depressive disorder in PD.

\section{METHODS}

We followed the PRISMA model (Preferred Reporting Items for Systematic reviews and Meta-Analyses).

\section{ELIGIBILITY CRITERIA}

(a) Studies: to evaluate the efficacy and safety of pharmacological treatments on cognitive dysfunction and major depressive disorder in $\mathrm{PD}$, we selected clinical trials, cross-sectional observational studies and case-control studies. However, only English language articles published from 2004 to 2014 were included.

(b) Participants: PD patients (>18 years old; both genders) with diagnostic of cognitive dysfunction or major depressive disorder according to the DSM-IV (diagnostic and statistical manual of mental disorders) criteria including depressed mood or a loss of interest or pleasure in daily activities for more than 2 weeks (mood represents a change from the person's baseline); impaired function (social, occupational, educational); specific symptoms [at least five of the following nine present nearly every day: (1) depressed mood or irritability most of the day, as indicated by either subjective report or observation made by others; (2) decreased interest or pleasure in most activities, most of each day; (3) significant weight change $(5 \%)$ or change in appetite; (4) change in sleep, whether insomnia or hypersomnia; (5) change in activity; (6) fatigue or loss of energy; (7) guilt/worthlessness; (8) concentration impairment: diminished ability to think or concentrate, or more indecisiveness; (9) suicidality: thoughts of death or having a suicide plan].

(c) Intervention: pharmacological therapy.

(d) Outcome measures: efficacy, safety, and QoL.

\section{SOURCES OF INFORMATION}

We included articles from PubMed electronic database updated until May, 2014. MeSH terms (Medical subject headings) used for the search were "parkinson disease," "Delirium," "Dementia," "Amnestic," "Cognitive disorders," "depression," "major depressive disorder," and "drug therapy."

\section{ARTICLE SELECTION}

Articles were evaluated by filtering the studies through analysis of the title, followed by summary and critical analysis of the full article. To evaluate the methodological quality of the randomized clinical trials, we used the CONSORT criteria (Consolidated Standards of Reporting Trials) available on http://www.consortstatement.org.

\section{DATA SEARCH}

The following data were extracted from the selected articles: authors, type of study, participant's characteristics, pharmacological intervention, diagnostic criteria, scales, efficacy of intervention, safety of the intervention, and QoL.

\section{EXCLUSION CRITERIA}

Studies without pharmacological treatment strategies were excluded. The selection and evaluation of the articles were made by two separated blinded authors.

\section{BIAS RISK ASSESSMENT}

We analyzed eligibility criteria for participants of the sample; the random allocation of participants, the presence of a control group, the results from the analysis of more than $85 \%$ of the sample, the presentation of results, and the inter group variability of the results. A sensitivity analysis of included data was not performed.

\section{RESULTS}

The search generated a total of 350 studies: 279 related to major depressive disorder and 71 to cognitive dysfunction. One hundred ninety-nine articles were excluded because of non-focus on pharmacological intervention; 89 were excluded because of non-satisfied MeSH selection criteria; 38 were excluded due to a 
poor/non-rigorous study design, publication date, use of other therapies and/or insufficient data. After all the inclusion and exclusion criteria were fulfilled, 24 articles remained: 13 for cognitive dysfunction and 11 for major depressive disorder. Those articles are presented and discussed in this study. The CONSORT flow diagram is shown in Figure 1.

\section{COGNITIVE DYSFUNCTION AND PARKINSON'S DISEASE}

For cognitive dysfunction in PD, 13 articles were analyzed (22-34). All of them were clinical trials (see Table 1). Neither cross-sectional observational studies nor case-control studies were found. All, except one, included patients with PDD. In total, 3853 patients were studied (see Table 1). All articles were obtained in full-text version and critically analyzed.

Pharmacological treatments used in these clinical studies were rivastigmine (3-12 $\mathrm{mg}$ ) during 24 weeks, rivastigmine $(1.5-6 \mathrm{mg})$ during 24 weeks, donepezil (5-10 mg) during 20 weeks, donepezil (5-10 mg) during 24 weeks, galantamine (8-16) during 24 weeks, memantine $(20 \mathrm{mg})$ during 52 weeks, memantine $(20 \mathrm{mg})$ during 22 weeks, and rasagiline ( $1 \mathrm{mg}$ ) during 12 weeks.

Cognitive dysfunction was defined as impairment in two out of four cognitive domains in screening neuropsychological tests.
All but two studies used the DSM-IV diagnostic criteria for PDD (the other two used ICD-10). Seven of eight studies used structured interviews as mini international neuropsychiatric interview (MINI) or structured clinical interview (SCI). The main outcomes were efficacy, safety, and QoL.

To identify the efficacy, all clinical studies evaluated pharmacological treatment response and improvement of cognitive dysfunction; nevertheless, the authors used different scales: cognitive subscale of Alzheimer's disease assessment scale (ADAS$\operatorname{cog}$ ), Alzheimer's disease cooperative study - clinician's global impression of change (ADCS-CGIC), Alzheimer's disease cooperative study activities of daily living (ADCS-ADL), 10-item neuropsychiatric inventory (NPI-10), mini-mental state examination (MMSE), computerized assessment system power of attention tests (CDR), verbal fluency test from the DelisKaplan executive function system (D-KEFS), clinician's interviewbased impression of change plus caregiver input (CIBIC+; global function), frontal lobe dysfunction assessment battery (FAB), neuropsychiatric inventory (NPI-12), disability assessment dementia (DAD), dementia rating scale (DRS), trail making test (TMT), and nurses observation scale for geriatric patients (NOS).

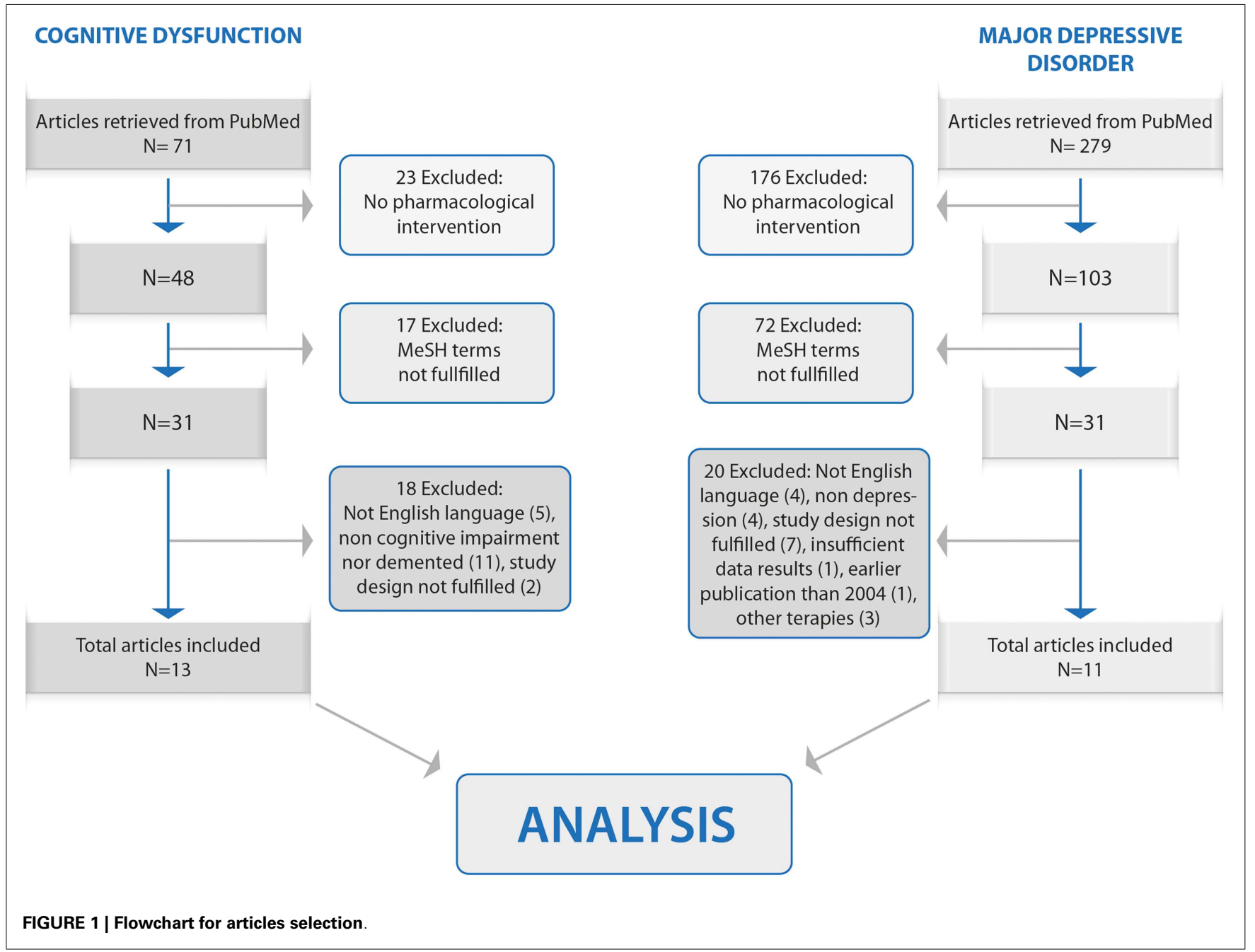




\begin{tabular}{|c|c|c|c|c|c|c|c|}
\hline Reference & Study & Intervention & Population & Scales used & Efficacy & Safety & Quality of life \\
\hline $\begin{array}{l}\text { Emre } \\
\text { et al. (22) }\end{array}$ & $\begin{array}{l}\text { Clinical } \\
\text { trial }\end{array}$ & $\begin{array}{l}\text { Rivastigmine } \\
3-12 \mathrm{mg} / \text { day }\end{array}$ & $\begin{array}{l}541 \text { PDD } \\
\text { patients }\end{array}$ & $\begin{array}{l}\text { ADAS-cog, ADCS-CGIC, } \\
\text { ADCS-ADL, NPI-10, MMSE, } \\
\text { CDR, D-KEFS }\end{array}$ & $\begin{array}{l}\text { Moderate significant efficacy in global ratings of } \\
\text { dementia and cognition }(p<0.0005)\end{array}$ & $\begin{array}{l}\mathrm{AE} \text { in } 83.7 \% \text { of patients in } \\
\text { rivastigmine group. Mild to } \\
\text { moderate events }\end{array}$ & Not evaluated \\
\hline $\begin{array}{l}\text { Poewe } \\
\text { et al. (26) }\end{array}$ & $\begin{array}{l}\text { Clinical } \\
\text { trial }\end{array}$ & $\begin{array}{l}\text { Rivastigmine } \\
1.5-6 \mathrm{mg} / \text { day }\end{array}$ & $\begin{array}{l}334 \text { PDD } \\
\text { patients }\end{array}$ & $\begin{array}{l}\text { ADAS-cog, ADCS-ADL, NPI-10, } \\
\text { MMSE, D-KEFS }\end{array}$ & $\begin{array}{l}\text { Improved cognitive performance above baseline } \\
\text { for up to } 48 \text { weeks }\end{array}$ & $\mathrm{AE}$ in $75.4 \%$ of patients & Not evaluated \\
\hline $\begin{array}{l}\text { Burn et al. } \\
(25,35)\end{array}$ & $\begin{array}{l}\text { Clinical } \\
\text { trial }\end{array}$ & $\begin{array}{l}\text { Rivastigmine } \\
3-12 \mathrm{mg} / \text { day }\end{array}$ & $\begin{array}{l}536 \text { PDD } \\
\text { patients }\end{array}$ & $\begin{array}{l}\text { ADAS-cog, ADCS-CGIC, } \\
\text { ADCS-ADL, D-KEFS, CDR, } \\
\text { MMSE, NPI-10 }\end{array}$ & $\begin{array}{l}\text { Greater benefits in patients with visual } \\
\text { hallucinations }(p<0.005)\end{array}$ & $\begin{array}{l}\text { Nausea and vomiting were } \\
\text { the most commonly AE }\end{array}$ & Not evaluated \\
\hline $\begin{array}{l}\text { Barone } \\
\text { et al. (27) }\end{array}$ & $\begin{array}{l}\text { Clinical } \\
\text { trial }\end{array}$ & $\begin{array}{l}\text { Rivastigmine } \\
7.8-8.4 \mathrm{mg} / \mathrm{day}\end{array}$ & $\begin{array}{l}342 \text { PDD } \\
\text { patients }\end{array}$ & $\begin{array}{l}\text { ADAS-cog, ADCS-CGIC, } \\
\text { ADCS-ADL, CDR }\end{array}$ & $\begin{array}{l}\text { Patients with elevated homocysteine levels had } \\
\text { greater effects on cognition }(p<0.01)\end{array}$ & $\begin{array}{l}\text { Severe AE were more } \\
\text { commonly in those with } \\
\text { elevated homocysteine }\end{array}$ & Not evaluated \\
\hline $\begin{array}{l}\text { Wesnes } \\
\text { et al. (24) }\end{array}$ & $\begin{array}{l}\text { Clinical } \\
\text { trial }\end{array}$ & $\begin{array}{l}\text { Rivastigmine } \\
3-12 \mathrm{mg} / \text { day }\end{array}$ & $\begin{array}{l}541 \text { PDD } \\
\text { patients }\end{array}$ & CDR & $\begin{array}{l}\text { Improvement on power of attention, continuity of } \\
\text { attention, cognitive reaction time and reaction time } \\
(p<0.01)\end{array}$ & Not evaluated & Not evaluated \\
\hline $\begin{array}{l}\text { Schmitt } \\
\text { et al. (32) }\end{array}$ & $\begin{array}{l}\text { Clinical } \\
\text { trial }\end{array}$ & $\begin{array}{l}\text { Rivastigmine } \\
3-12 \mathrm{mg} / \text { day }\end{array}$ & $\begin{array}{l}402 \text { PDD } \\
\text { patients }\end{array}$ & D-KEFS & $\begin{array}{l}\text { Significant effects on tests of letter fluency, card } \\
\text { sorting, and symbol digit modalities }(p<0.05)\end{array}$ & Not evaluated & Not evaluated \\
\hline $\begin{array}{l}\text { Olin } \\
\text { et al. (31) }\end{array}$ & $\begin{array}{l}\text { Clinical } \\
\text { trial }\end{array}$ & $\begin{array}{l}\text { Rivastigmine } \\
3-12 \mathrm{mg} / \text { day }\end{array}$ & $\begin{array}{l}402 \text { PDD } \\
\text { patients }\end{array}$ & ADCS-ADL & $\begin{array}{l}\text { Modest beneficial effects on basic and higher } \\
\text { level ADL functioning }\end{array}$ & Not evaluated & Not evaluated \\
\hline $\begin{array}{l}\text { Ravina } \\
\text { et al. (23) }\end{array}$ & $\begin{array}{l}\text { Clinical } \\
\text { trial }\end{array}$ & $\begin{array}{l}\text { Donepezil } \\
5-10 \mathrm{mg} / \mathrm{day}\end{array}$ & $\begin{array}{l}22 \text { PDD } \\
\text { patients }\end{array}$ & ADAS-cog, MMSE, DRS & $\begin{array}{l}\text { Modest effect on cognitive function according to } \\
\text { MMSE }\end{array}$ & $A E$ in $52 \%$ of patients & Not evaluated \\
\hline $\begin{array}{l}\text { Dubois } \\
\text { et al. (34) }\end{array}$ & $\begin{array}{l}\text { Clinical } \\
\text { trial }\end{array}$ & $\begin{array}{l}\text { Donepezil } \\
5-10 \mathrm{mg} / \mathrm{day}\end{array}$ & $\begin{array}{l}550 \text { PDD } \\
\text { patients }\end{array}$ & ADAS-cog, CIBIC + & $\begin{array}{l}\text { Evidence suggesting cognition and execution } \\
\text { function improvement in Parkinson's disease } \\
\text { dementia }\end{array}$ & $\begin{array}{l}\text { Higher incidence of adverse } \\
\text { effects in the donepezil } \\
\text { treated groups }\end{array}$ & Not evaluated \\
\hline $\begin{array}{l}\text { Litvinenko } \\
\text { et al. (28) }\end{array}$ & $\begin{array}{l}\text { Clinical } \\
\text { trial }\end{array}$ & $\begin{array}{l}\text { Galantamine } \\
8-16 \mathrm{mg}\end{array}$ & $\begin{array}{l}41 \text { PDD } \\
\text { patients }\end{array}$ & $\begin{array}{l}\text { MMSE, ADAS-cog, FAB, CDT, } \\
\text { NPI-12, DAD }\end{array}$ & $\begin{array}{l}\text { Positive effects on the overall level of cognitive } \\
\text { impairments assessed on the MMSE and } \\
\text { ADAS-cog scales }(p<0.05)\end{array}$ & $\mathrm{AE}$ in $30 \%$ of patients & Not evaluated \\
\hline $\begin{array}{l}\text { Litvinenko } \\
\text { et al. (30) }\end{array}$ & $\begin{array}{l}\text { Clinical } \\
\text { trial }\end{array}$ & $\begin{array}{l}\text { Memantine } \\
20 \mathrm{mg} / \text { day }\end{array}$ & $\begin{array}{l}62 \text { PDD } \\
\text { patients }\end{array}$ & $\begin{array}{l}\text { MMSE, ADAS-cog, FAB, D-KEFS, } \\
\text { CDR, NPI-12, DAD }\end{array}$ & $\begin{array}{l}\text { Positive effects on the overall level of cognitive } \\
\text { impairments assessed on the MMSE and } \\
\text { ADAS-cog scales }(p<0.05)\end{array}$ & $A E$ in $3 / 32$ patients & Not evaluated \\
\hline $\begin{array}{l}\text { Leroi } \\
\text { et al. (29) }\end{array}$ & $\begin{array}{l}\text { Clinical } \\
\text { trial }\end{array}$ & $\begin{array}{l}\text { Memantine } \\
20 \mathrm{mg} / \text { day }\end{array}$ & $\begin{array}{l}25 \text { PDD } \\
\text { patients }\end{array}$ & DRS, NPI, MMSE, CIBIC-Plus & Statically significant benefit on MMSE & $\begin{array}{l}1 \mathrm{AE} \text {, unlikely to be related } \\
\text { to the study medication }\end{array}$ & Not evaluated \\
\hline $\begin{array}{l}\text { Hanagasi } \\
\text { et al. (33) }\end{array}$ & $\begin{array}{l}\text { Clinical } \\
\text { trial }\end{array}$ & $\begin{array}{l}\text { Rasagiline } \\
1 \mathrm{mg} / \text { day }\end{array}$ & $\begin{array}{l}55 \text { PD-MCl } \\
\text { patients }\end{array}$ & CDR, Stroop test, TMT A and B & $\begin{array}{l}\text { Beneficial effects on certain aspects of cognition in } \\
\text { tests of attention and executive functions }(p<0.05)\end{array}$ & $3 \mathrm{AE}$ reported & Not evaluated \\
\hline
\end{tabular}

Parkinson's disease dementia (PDD), mild cognitive impairment (MCl), adverse events (AE), cognitive subscale of the Alzheimer's disease assessment scale (ADAS-cog), Alzheimer's disease cooperative studyclinician's global impression of change (ADCS-CGIC), Alzheimer's disease cooperative study activities of daily living (ADCS-ADL), 10-item neuropsychiatric inventory (NPI-10), mini-mental state examination (MMSE), computerized assessment system power of attention tests (CDR), verbal fluency test from the Delis-Kaplan executive function system (D-KEFS), clinician's interview-based impression of change plus caregiver input (CIBIC+; global function), frontal lobe dysfunction assessment battery (FAB), neuropsychiatric inventory (NPI-12), disability assessment dementia (DAD), dementia rating scale (DRS), trail making test (TMT). 


\section{MAJOR DEPRESSIVE DISORDER AND PARKINSON'S DISEASE}

Eleven articles were analyzed (20,36-45). All of them were clinical trials (see Table 2). Neither cross-sectional observational studies nor case-control studies were found. In total, 510 patients were studied (Table 2). All articles were obtained in full-text version and critically analyzed.

Pharmacological treatments used in the studies were duloxetine $(60 \mathrm{mg} /$ day $)$ during 12 weeks, nortriptyline $(25-75 \mathrm{mg})$ during 8 weeks, paroxetine (continuous release $12.5-37.5 \mathrm{mg}$ ) during 12 weeks, citalopram ( $10-30 \mathrm{mg} /$ day) during 12 weeks, Omega-3 (4 capsules/day) during 3 months, escitalopram ( $20 \mathrm{mg} /$ day) during 12 weeks, pramipexole ( $1.5-4.5 \mathrm{mg} /$ day) during 14 weeks, sertraline $(50 \mathrm{mg} /$ day $)$ during 14 weeks, reboxetine (3.75-4.2 mg/day) during 4 months, rasagiline ( $1-2 \mathrm{mg} /$ day) during 8 weeks, desipramine $(75 \mathrm{mg} /$ day $)$, and citalopram (20 $\mathrm{mg} /$ day) during 14 and 30 days.

All the studies used the DSM-IV major depressive disorder diagnostic criteria for enrollment patients; 8 of the 11 studies also used structured interviews as MINI or SCI. The main outcomes to be measured were efficacy, safety, and QoL.

To identify the efficacy, those clinical studies evaluated the response to pharmacological treatments and remission of depression; nevertheless, the authors used different scales: HAMD (clinical response defined as a $50 \%$ reduction in baseline to endpoint score and remission defined as a $<8$ score), BDI, clinical global impression-severity (CGI-S), clinical global impression improvement scale (CGI-I), MADRS, inventory of depressive symptomatology (IDS), GDS, and the hospital anxiety and depression scale (HADS). One study evaluated efficacy through brain structural changes in single-photon emission computed tomography (SPECT).

Seven articles evaluated the safety of pharmacological therapy. Side effects were used as outcome measure. To assess the QoL some studies used the Nottingham quality of life scale (NHP), Parkinson disease questionnaire (PDQ8), and the short form health survey (SF-36).

Two clinical trials with PD patients and major depressive disorder evaluated the use of selective serotonin reuptake inhibitor (SSRIs) citalopram at doses of $10-30 \mathrm{mg} /$ day. The treatment response was measured by cerebral blood flow using SPECT scan. Larger cortical areas were found to be involved in depressed PD patients with hyperactivity (reciprocal to basal degeneration in PD and maybe dopaminergic treatment) and with hypoactivity (probably due to organic lesions leading to hypoperfusion). Measurement of monoamines levels, brain-derived neurotrophic factor (BDNF), orexin-A, interleukin 6 (IL-6), and corticosterone in the cerebrospinal fluid reported low levels of BDNF and IL6. Both studies registered improvement in depressive symptoms without reporting efficacy, side effects, and QoL. The treatment response using escitalopram (dose of $20 \mathrm{mg}$ /day) was 37\%; depression remission was $50 \% ; 14 \%$ of the population reported side effects (nausea and confusion), but this study did not report effects on QoL.

From these 11 studies, 63\% reported security. Duloxetine was the drug that reported higher percentage of side effects (20.5\%). Main side effects were diarrhea, tremor, nausea, vomiting, drowsiness, syncope, visual hallucinations, decreased libido, and psychotic symptoms.

One study compared a dopamine agonist (pramipexole) versus SSRI (sertraline). Patients included in the study showed no motor symptoms; PD patients with major depressive disorder without motor symptoms treated with pramipexole had a better treatment response and remission of the major depressive disorder in $60 \%$ of patients with $<10 \%$ of side effects compared with sertraline; no difference was observed in QoL between the two drugs.

Another study tested fatty acids (Omega-3) in combination with antidepressants: sertraline, tricyclic antidepressants, and trazodone. It found an efficacy $>40 \%$ compared with the placebo group.

Treatment with rasagiline (MAO-B) was associated with improvement in mood, especially at doses of $2 \mathrm{mg}$. Desipramine (tricyclic antidepressant) and citalopram (SSRIs) were compared showing an improvement in the acute treatment on day 14 with the tricyclic antidepressant and improvement with both antidepressants in the 30th, but side effects were reported (bradykinesia with citalopram, erectile dysfunction, and orthostatic hypotension with desimipramine).

The analyzed studies, however, did not specify the major depressive disorder domains in which the drugs had an effect.

\section{DISCUSSION \\ COGNITIVE DYSFUNCTION}

All except one trial included patients with PDD, situation which reflects the difficulties in designing studies in groups with heterogeneous cognitive profiles, such as those seen in MCI-PD and early stages of PDD.

Although rivastigmine appears to be the most consistent treatment, all clinical trials are from the same population studied by the same group (22). Even when the study of the same population allows to compare every clinical trial between each other and to get more confident conclusions about doses and duration of treatment, those may not be valid to other populations. Taking that into account, it may be recommendable to conduct clinical trials in different populations to compare results and to ensure a correct generalization of the conclusions.

It is important to note that even though the multinational trial by Dubois et al. with donepezil did not meet its planned primary objective, the alternative ADAS-cog analysis while removing the treatment-by-country interaction from the model, revealed a significant, dose-dependent benefit with donepezil. Authors attributed this to possible imbalance in enrollment between participant countries (34). This finding is consistent with clinical practice, where caregivers report improvement in cognition of their patients when donepezil is prescribed.

Patients with PDD were included according to the DSM-IV criteria (which requires the presence of memory impairment), and while analyzing the efficacy of treatment, we found that most primary outcomes were assessed with ADAS-cog (see Table 1), a scale designed to assess the severity of the major symptoms of Alzheimer. The main areas of the cognitive domains evaluated with this scale are memory (50\%), language (28\%), praxis (14\%), and command understanding (8\%) (46); however, this scale lacks 
Table 2 | Rational pharmacological approaches for major depressive disorder in Parkinson's disease.

\begin{tabular}{|c|c|c|c|c|c|c|c|}
\hline Reference & Study & Intervention & Population & Scales used & Efficacy & Safety & Quality of life \\
\hline $\begin{array}{l}\text { Bonuccelli } \\
\text { et al. (44) }\end{array}$ & $\begin{array}{l}\text { Clinical } \\
\text { trial }\end{array}$ & $\begin{array}{l}\text { Duloxetine } \\
60 \mathrm{mg}\end{array}$ & 151 Patients & $\begin{array}{l}\text { HAMD-17, BDI, } \\
\text { CGI-S, PDQ-39 }\end{array}$ & $\begin{array}{l}\text { Response }(60.4 \%) \text { and remission } \\
(45.6 \%)\end{array}$ & $\begin{array}{l}\text { Adverse events reported in } \\
20.5 \% \text { of patients }\end{array}$ & $\begin{array}{l}\text { Significant improvement ( } p<0.001) \\
\text { on emotional well being, stigma, } \\
\text { cognitive impairment, and bodily } \\
\text { discomfort, as measured by PDQ-39 }\end{array}$ \\
\hline $\begin{array}{l}\text { Dobkin } \\
\text { et al. (43) }\end{array}$ & $\begin{array}{l}\text { Clinical } \\
\text { trial }\end{array}$ & $\begin{array}{l}\text { Nortriptyline } \\
(25-75 \mathrm{mg}) \\
\text { paroxetine } \\
(12.5-37.5 \mathrm{mg})\end{array}$ & $\begin{array}{l}52 \text { Patients: } \\
\text { paroxetine } 18, \\
\text { nortriptyline } 17 \\
\text { placebo } 17\end{array}$ & $\begin{array}{l}\text { HAMD-17, CGI-I, } \\
\text { HAMA }\end{array}$ & $\begin{array}{l}\text { Response to acute treatment in } 16 \\
\text { patients: paroxetine (3), nortriptyline } \\
\text { (9), placebo (4) }\end{array}$ & Not evaluated & Not evaluated \\
\hline $\begin{array}{l}\text { Palhagen } \\
\text { et al. (42) }\end{array}$ & $\begin{array}{l}\text { Clinical } \\
\text { trial }\end{array}$ & $\begin{array}{l}\text { Citalopram } \\
10-30 \mathrm{mg} / \mathrm{day}\end{array}$ & $\begin{array}{l}37 \text { Patients: PD + MD } \\
\text { (11), PD (14), MD (12) }\end{array}$ & $\begin{array}{l}\text { HAMD-17, } \\
\text { MADRS }\end{array}$ & $\begin{array}{l}\text { Modest effect on cognitive function } \\
\text { according to MMSE }\end{array}$ & Not evaluated & Not evaluated \\
\hline $\begin{array}{l}\text { Palhagen } \\
\text { et al. (40) }\end{array}$ & $\begin{array}{l}\text { Clinical } \\
\text { trial }\end{array}$ & $\begin{array}{l}\text { Citalopram } \\
10-30 \mathrm{mg} / \text { day }\end{array}$ & $\begin{array}{l}37 \text { Patients: PD + MD } \\
\text { (11), PD (14), MD (12) }\end{array}$ & $\begin{array}{l}\text { HAMD-17, } \\
\text { MADR, SPECT }\end{array}$ & $\begin{array}{l}\text { Expected decrease in the } 5 \text { HIAA and } \\
\text { MHPG levels in patients with solely } \\
\text { MD, but not in PD patients with MD. } \\
\text { Levels of BDNF and IL-6 were lower in } \\
\text { the PD patients }\end{array}$ & Not evaluated & Not evaluated \\
\hline $\begin{array}{l}\text { Da Silva } \\
\text { et al. (20) }\end{array}$ & $\begin{array}{l}\text { Clinical } \\
\text { trial }\end{array}$ & $\begin{array}{l}\text { Omega-3 } 4 \\
\text { capsules }\end{array}$ & $\begin{array}{l}17 \text { Patients: Omega-3 } \\
\text { (7), placebo (10) }\end{array}$ & $\begin{array}{l}\text { MADRS, BDI, } \\
\text { CGI }\end{array}$ & $\begin{array}{l}\text { Positive effects on the overall level of } \\
\text { cognitive impairments assessed on the } \\
\text { MMSE and ADAS-cog scales }(p<0.05)\end{array}$ & Not evaluated & Not evaluated \\
\hline $\begin{array}{l}\text { Weintraub } \\
\text { et al. (38) }\end{array}$ & $\begin{array}{l}\text { Clinical } \\
\text { trial }\end{array}$ & $\begin{array}{l}\text { Escitalopram } \\
20 \mathrm{mg}\end{array}$ & 14 Patients & HAMD, IS, CGI-I & $42 \%$ of patients responded & $\begin{array}{l}\text { Adverse events reported in } \\
2 \text { patients (nausea and } \\
\text { confusion) }\end{array}$ & Not evaluated \\
\hline $\begin{array}{l}\text { Barone } \\
\text { et al. (36) }\end{array}$ & $\begin{array}{l}\text { Clinical } \\
\text { trial }\end{array}$ & $\begin{array}{l}\text { Pramipexole } \\
1.5-4.5 \mathrm{mg} / \text { day, } \\
\text { sertraline } \\
50 \mathrm{mg} / \text { day }\end{array}$ & 67 Patients & HAMD-17, SF-36 & $\begin{array}{l}\text { Larger cortical areas were found to be } \\
\text { involved in depressed PD patients, } \\
\text { both with hyperactivity and with } \\
\text { hypoactivity }\end{array}$ & $\begin{array}{l}\text { Adverse events reported in } \\
3 \text { patients on the pramipexole } \\
\text { group and in } 8 \text { on the } \\
\text { sertraline group }\end{array}$ & $\begin{array}{l}\text { General improvement for both } \\
\text { groups }\end{array}$ \\
\hline $\begin{array}{l}\text { Pintor } \\
\text { et al. (37) }\end{array}$ & $\begin{array}{l}\text { Clinical } \\
\text { trial }\end{array}$ & $\begin{array}{l}\text { Reboxetine } \\
3.74-4.2 \mathrm{mg} / \text { day }\end{array}$ & 17 Patients & $\begin{array}{l}\text { HAMD, GDS, } \\
\text { HADS, NHP }\end{array}$ & $\begin{array}{l}\text { Improvement of } 50 \% \text { at the HAMD } \\
\text { scores in } 12 \text { patients. HAD mean } \\
\text { scores decreased by } 59.34 \text { and } \\
52.01 \% \text { at the GDS. }\end{array}$ & $\begin{array}{l}\text { Adverse events reported in } 2 \\
\text { patients (vertigo and redness) }\end{array}$ & $\begin{array}{l}\text { Mean scores on the NHP } \\
\text { decreased by } 44.59 \%\end{array}$ \\
\hline $\begin{array}{l}\text { Korchounov } \\
\text { et al. (45) }\end{array}$ & $\begin{array}{l}\text { Clinical } \\
\text { trial }\end{array}$ & $\begin{array}{l}\text { Rasagiline } \\
1-2 \mathrm{mg} / \text { day }\end{array}$ & 6 Patients & HAMD-17 & $\begin{array}{l}\text { Subjects treated with } 2 \mathrm{mg} / \mathrm{d} \text { scored } \\
<14 \text { after treatment at HDRS score }\end{array}$ & $\begin{array}{l}\text { Adverse effects or insomnia } \\
\text { were not reported }\end{array}$ & $\begin{array}{l}\text { Improvement was more } \\
\text { pronounced if treated with } 2 \mathrm{mg} \\
\text { of rasagiline }(p=0.20)\end{array}$ \\
\hline
\end{tabular}




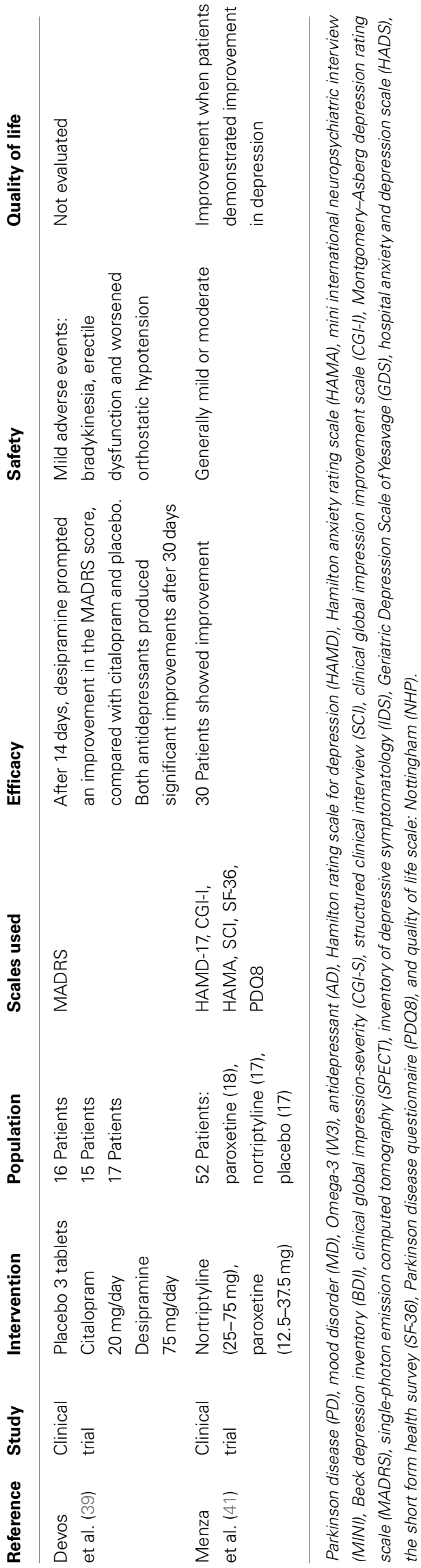

specificity for PDD due to obvious differences in the profiles of these two conditions; the predominance of memory impairment in the first one and the "dysexecutive" impairment on the second one. The fact that patients were included with the DSM-IV criteria and that the instrument utilized to assess the primary end point of efficacy was the ADAS-cog makes that the results of the studies focused mainly in domains usually affected in Alzheimer's disease but not in those related with the cognitive profile in PDD.

Comparative studies used in the task force for clinical diagnostic criteria for dementia associated with Parkinson's disease matched dementia on the basis of the DRS. Therefore, it has been suggested as an alternative to assess efficacy in clinical trials with cholinesterase inhibitors for PDD, given its sensitivity for the diagnosis of executive dysfunction (47). This scale was used as a part of the secondary objective in two studies of the current review.

Task force has made recommendations about the test for use in the diagnosis of PDD (48) and PD-MCI (2). Measures specific to PD have the advantage that they emphasize testing cognitive deficits associated with PD (e.g., executive and visuospatial deficits) whereas generic measures tend to focus on memory abilities. Scales designed to asses cognitive impairment associated with PD include the Parkinson's disease dementia - short screen (PDDSS) (49), the Parkinson neuropsychiatric dementia assessment (PANDA) (50), the mini-mental Parkinson (MMP) (51), the scales for outcomes of Parkinson's disease - cognition (SCOPA-Cog) (52), and the Parkinson's disease cognitive rating scale (PD-CRS) (53). All of them with good diagnostic accuracy and some need a minimum of time for administration. Formal assessment of each domain requires more detailed neuropsychological tests. Future studies will benefit from using these ones and will allow more definitive conclusions.

When conducting clinical trials about treatment for cognitive dysfunction, it is important to take into account the presence of neuropsychiatric symptoms; depression, apathy, anxiety, and irritability, are frequent in non-demented PD patients (54). The first two can affect the cognitive performance on neuropsychological tests since they have been negatively associated with executive functioning and with immediate memory (55). Although not all, most of the studies of the current review, state that the presence of depression was an exclusion criterion, partly eliminating in this way potential sources of confusion.

The association between cognitive dysfunction and depressive symptoms has a possible underlying mechanism in common, which in some studies has been related to acetylcholine. In this respect, Bohnen et al. demonstrated a significant inverse correlation between cortical AChE activity and the scores of the Cornell scale for depression in dementia. This correlation remained significant after controlling for mini-mental state examination scores (56). Moreover, Meyer et al. reported in vivo reductions of $\alpha 4 \beta 2 \mathrm{nAChRs}$ in PD that correlated with both increased severity of depressive symptoms and severity of cognitive symptoms (57).

Studies indicate that the clinical phenotype is also associated with dementia, patients with a tremor-dominant phenotype are rare to present dementia (58), while in patients with axial symptoms dementia is developed earlier in the course of the disease (35). Moreover, in a recent meta-analysis, patients with nontremor predominant motor symptoms had more severe cognitive 
impairments than tremor-dominant patients. Results of this study also suggested that PD subgroups with depression had more severe cognitive impairment. Because of the influence of depression and the subtype of predominant motor symptoms on cognition authors consider important to take them into account when evaluating a cognitive profile in PD (59). It would be interesting to determine if certain clinical phenotype benefits more from therapy, which also could indicate or reinforce the implicated mechanisms of cognitive dysfunction in these patients.

Nevertheless, none of the studies assessed QoL (see Table 1). QoL is nowadays considered a unique and irreplaceable assessment for clinical evaluation. Instead of QoL, the ADCS-ADL scale was used. This scale can indirectly quantify the QoL of patients and care givers. However, the activities assessed by the scale can be related to both, cognitive impairment and motor symptoms, which can be a confounder if appropriate measures are not taken.

Although the unified Parkinson's disease rating scale (UPDRS) was assessed before and after each study, the ON/OFF status of the patient is not mentioned during the neuropsychological assessment of the patient, which can influence the scores that require motor responses.

Unfortunately, only one study included patients with PD-MCI, it revealed that rasagiline may confer some beneficial effects on certain aspects of cognition in this patient population (33). The relevance of the $\mathrm{PD}-\mathrm{MCI}$ as a risk factor for the development of PDD, makes this study a start point for future studies aiming to treat and prevent PDD. New clinical criteria for diagnosing PDMCI will allow uniform inclusion for PD patients' in new clinical trials.

In spite of this limitations, studies showed benefit in the primary endpoint for rivastigmine and if removing the treatment-bycountry interaction, also for donepezil. A recent study assessing the efficacy of cholinestarease inhibitors in PDD, MCI-PD, and Lewy body dementia concluded that the beneficial effect on cognitive function was observed in both the donepezil and rivastigmine groups (SMD $-0.42,95 \% \mathrm{CI}-0.58$ to $-0.25, p<0.00001$; SMD $-0.27,95 \% \mathrm{CI}-0.44$ to $-0.11, p<0.001$, respectively) (60).

In the near future, it would be interesting to conduct functional studies in combination with biomarkers in order to determine additional mechanisms for PDD.

\section{MAJOR DEPRESSIVE DISORDER}

All articles reviewed in this study aimed to treat major depressive disorder in PD patients mainly by the use of SSRIs antidepressants. This type of antidepressants is often used in clinical practice, despite possible side effects as nausea, vomiting, sexual dysfunction, diarrhea, and auditory hallucinations (21).

Two clinical trials included in this review reported response to citalopram treatment measured by cerebral blood flow by SPECT (40) and monoamine levels, BDNF, orexin-A, IL-6, and corticosterone in the cerebrospinal fluid (42), but did not study side effects. These studies only reported an improvement in depressive symptoms without outcome measures as efficacy, side effects or QoL (see Table 2). One study reported side effects with citalopram (bradykinesia) (39).
A study treating patients with dopamine agonists reported a reduction of depression symptoms; however, the mechanism of this reduction is not clear (36). We could suggest an indirect effect associated with improvement on motor symptoms. The authors compared pramipexole with sertraline to treat major depressive disorder in PD patients without history of motor symptoms. The pramipexole group had a greater response to treatment, remission of depression symptoms, and fewer side effects compared with the sertraline group (36).

The antidepressant effect of rasagiline was obtained with higher doses than those used for motor control symptoms ( $1 \mathrm{mg} /$ day). The authors suggesting that the improvement in mood is not a direct result of the improvement in motor function.

Selective serotonin reuptake inhibitor, serotonin-norepinephrine reuptake inhibitors (SNRIs), selective noradrenaline recapture inhibitor, and tricyclic antidepressants (TCAs) seem to be a good strategy to treat PD patients. Nevertheless, the non-homogeneous methodology used in the studies to assess outcome measures and the limited number of studies focused on these drugs complicate a statistical analysis and getting a conclusion by a meta-analysis. SSRIs are the most studied drugs, reporting a high rate of response to treatment and remission of the symptoms associated with major depressive disorder (21). The American Academy of Neurology declared that there is insufficient evidence to recommend specific antidepressant treatments for major depression disorder in PD patients (61). Considering that this is a chronic and severe disability condition, the economic impact for the patient suffering from this condition is high. Therefore, the development of a treatment guideline for patients with PD and major depressive disorder is necessary.

\section{CONCLUSION}

Here, we ask the question "are these current pharmacological strategies safe and efficient to treat cognitive dysfunction and depression in Parkinson's disease?"

Unfortunately not! There is insufficient evidence to recommend specific pharmacological treatment for these non-motor symptoms of $\mathrm{PD}$. Therefore, there is the need to conduct more clinical studies.

Finally, we must remember that, however, exciting the neurobiological mechanisms might be, the clinical usefulness of rational therapeutic approaches will be determined by their ability to provide efficacy, safety, long-lasting, and substantial improvements in QoL.

Most of the studies of cognitive dysfunction in Parkinson have been conducted in patients with dementia; however, the different prognosis in syndromes of cognitive impairment makes mandatory to develop studies since these stages where clinical trials are lacking.

Early MCI and PDD differences in cognitive profile will allow that disease modifying therapies may be targeted at the different dopaminergic and non-dopaminergic mechanisms involved in the pathophysiology of cognitive dysfunction in patients with Parkinson's disease.

It is necessary to design clinical trials according to criteria and end point measures specifically designed for MCI-PD and PDD, 
which will allow more definitive conclusions and understanding in this topic.

\section{ACKNOWLEDGMENTS}

We would like to thank the colleagues working at the "Unidad de Trastornos del Movimiento y Sueño (TMS)" from Hospital General Dr. Manuel Gea González and Hospital General Ajusco Medio. We sincerely thank the founding from "Secretaría de Ciencia, Tecnología e Innovación (SECITI)". OA-C is supported by CONACYT-BMBF 2013 (Grant 208132).

\section{REFERENCES}

1. Berg D, Lang AE, Postuma RB, Maetzler W, Deuschl G, Gasser T, et al. Changing the research criteria for the diagnosis of Parkinson's disease: obstacles and opportunities. Lancet Neurol (2013) 12:514-24. doi:10.1016/S1474-4422(13) 70047-4

2. Litvan I, Goldman JG, Troster AI, Schmand BA, Weintraub D, Petersen RC, et al. Diagnostic criteria for mild cognitive impairment in Parkinson's disease: movement disorder society task force guidelines. Mov Disord (2012) 27:349-56. doi: $10.1002 / \mathrm{mds} .24893$

3. Janvin CC, Larsen JP, Aarsland D, Hugdahl K. Subtypes of mild cognitive impairment in Parkinson's disease: progression to dementia. Mov Disord (2006) 21:1343-9. doi:10.1002/mds.20974

4. Goldman JG, Litvan I. Mild cognitive impairment in Parkinson's disease. Minerva Med (2011) 102:441-59.

5. Litvan I, Aarsland D, Adler CH, Goldman JG, Kulisevsky J, Mollenhauer B, et al. MDS task force on mild cognitive impairment in Parkinson's disease: critical review of PD-MCI. Mov Disord (2011) 26:1814-24. doi:10.1002/mds.23823

6. Mahieux F, Fenelon G, Flahault A, Manifacier MJ, Michelet D, Boller F. Neuropsychological prediction of dementia in Parkinson's disease. J Neurol Neurosurg Psychiatry (1998) 64:178-83. doi:10.1136/jnnp.64.2.178

7. Janvin CC, Aarsland D, Larsen JP. Cognitive predictors of dementia in Parkinson's disease: a community-based, 4-year longitudinal study. J Geriatr Psychiatry Neurol (2005) 18:149-54. doi:10.1177/0891988705277540

8. Williams-Gray CH, Mason SL, Evans JR, Foltynie T, Brayne C, Robbins TW, et al. The CamPaIGN study of Parkinson's disease: 10-year outlook in an incident population-based cohort. J Neurol Neurosurg Psychiatry (2013) 84:1258-64. doi:10.1136/jnnp-2013-305277

9. Hilker R, Thomas AV, Klein JC, Weisenbach S, Kalbe E, Burghaus L, et al. Dementia in Parkinson disease: functional imaging of cholinergic and dopaminergic pathways. Neurology (2005) 65:1716-22. doi:10.1212/01.wnl.0000191154. 78131.f6

10. Levy G, Jacobs DM, Tang MX, Cote LJ, Louis ED, Alfaro B, et al. Memory and executive function impairment predict dementia in Parkinson's disease. Mov Disord (2002) 17:1221-6. doi:10.1002/mds.10280

11. Hobson P, Meara J. Risk and incidence of dementia in a cohort of older subjects with Parkinson's disease in the United Kingdom. Mov Disord (2004) 19:1043-9. doi: $10.1002 / \mathrm{mds} .20216$

12. Aarsland D, Zaccai J, Brayne C. A systematic review of prevalence studies of dementia in Parkinson's disease. Mov Disord (2005) 20:1255-63. doi:10.1002/ mds. 20527

13. Emre M, Aarsland D, Brown R, Burn DJ, Duyckaerts C, Mizuno Y, et al. Clinical diagnostic criteria for dementia associated with Parkinson's disease. Mov Disord (2007) 22:1689-707. doi:10.1002/mds.21507

14. Irwin DJ, Lee VM, Trojanowski JQ. Parkinson's disease dementia: convergence of alpha-synuclein, tau and amyloid-beta pathologies. Nat Rev Neurosci (2013) 14:626-36. doi:10.1038/nrn3549

15. Ballard C, Ziabreva I, Perry R, Larsen JP, O’Brien J, Mckeith I, et al. Differences in neuropathologic characteristics across the Lewy body dementia spectrum. Neurology (2006) 67:1931-4. doi:10.1212/01.wnl.0000249130.63615.cc

16. Perry EK, Curtis M, Dick DJ, Candy JM, Atack JR, Bloxham CA, et al. Cholinergic correlates of cognitive impairment in Parkinson's disease: comparisons with Alzheimer's disease. J Neurol Neurosurg Psychiatry (1985) 48:413-21. doi:10.1136/jnnp.48.5.413

17. Cummings JL. Cholinesterase inhibitors for treatment of dementia associated with Parkinson's disease. J Neurol Neurosurg Psychiatry (2005) 76:903-4. doi:10.1136/jnnp.2004.061499
18. Veazey C, Aki SO, Cook KF, Lai EC, Kunik ME. Prevalence and treatment of depression in Parkinson's disease. J Neuropsychiatry Clin Neurosci (2005) 17:310-23. doi:10.1176/appi.neuropsych.17.3.310

19. Vanderheyden JE, Gonce M, Bourgeois P, Cras P, De Nayer AR, Flamez A, et al. Epidemiology of major depression in Belgian parkinsonian patients. Acta Neurol Belg (2010) 110:148-56.

20. Da Silva TM, Munhoz RP, Alvarez C, Naliwaiko K, Kiss A, Andreatini R, et al. Depression in Parkinson's disease: a double-blind, randomized, placebocontrolled pilot study of omega-3 fatty-acid supplementation. J Affect Disord (2008) 111:351-9. doi:10.1016/j.jad.2008.03.008

21. Hagikura M, Iwamoto K, Aleksic B, Ozaki N. What is a rational antidepressant treatment for major depression in patients with Parkinson's disease? Psychiatry Clin Neurosci (2012) 66:463. doi:10.1111/j.1440-1819.2012.02362.x

22. Emre M, Aarsland D, Albanese A, Byrne EJ, Deuschl G, De Deyn PP, et al. Rivastigmine for dementia associated with Parkinson's disease. $N$ Engl J Med (2004) 351:2509-18. doi:10.1056/NEJMoa041470

23. Ravina B, Putt M, Siderowf A, Farrar JT, Gillespie M, Crawley A, et al. Donepezil for dementia in Parkinson's disease: a randomised, double blind, placebo controlled, crossover study. J Neurol Neurosurg Psychiatry (2005) 76:934-9. doi:10.1136/jnnp.2004.050682

24. Wesnes KA, Mckeith I, Edgar C, Emre M, Lane R. Benefits of rivastigmine on attention in dementia associated with Parkinson disease. Neurology (2005) 65:1654-6. doi:10.1212/01.wnl.0000184517.69816.e9

25. Burn D, Emre M, Mckeith I, De Deyn PP, Aarsland D, Hsu C, et al. Effects of rivastigmine in patients with and without visual hallucinations in dementia associated with Parkinson's disease. Mov Disord (2006) 21:1899-907. doi:10. $1002 / \mathrm{mds} .21077$

26. Poewe W, Wolters E, Emre M, Onofrj M, Hsu C, Tekin S, et al. Long-term benefits of rivastigmine in dementia associated with Parkinson's disease: an active treatment extension study. Mov Disord (2006) 21:456-61. doi:10.1002/mds.20700

27. Barone P, Burn DJ, Van Laar T, Hsu C, Poewe W, Lane RM. Rivastigmine versus placebo in hyperhomocysteinemic Parkinson's disease dementia patients. Mov Disord (2008) 23:1532-40. doi:10.1002/mds.21997

28. Litvinenko IV, Odinak MM, Mogil'naya VI, Emelin AY. Efficacy and safety of galantamine (reminyl) for dementia in patients with Parkinson's disease (an open controlled trial). Neurosci Behav Physiol (2008) 38:937-45. doi:10.1007/ s11055-008-9077-3

29. Leroi I, Overshott R, Byrne EJ, Daniel E, Burns A. Randomized controlled trial of memantine in dementia associated with Parkinson's disease. Mov Disord (2009) 24:1217-21. doi:10.1002/mds. 22495

30. Litvinenko IV, Odinak MM, Mogil'naya VI, Perstnev SV. Use of memantine (akatinol) for the correction of cognitive impairments in Parkinson's disease complicated by dementia. Neurosci Behav Physiol (2010) 40:149-55. doi:10.1007/s11055-009-9244-1

31. Olin JT, Aarsland D, Meng X. Rivastigmine in the treatment of dementia associated with Parkinson's disease: effects on activities of daily living. Dement Geriatr Cogn Disord (2010) 29:510-5. doi:10.1159/000305100

32. Schmitt FA, Farlow MR, Meng X, Tekin S, Olin JT. Efficacy of rivastigmine on executive function in patients with Parkinson's disease dementia. CNS Neurosci Ther (2010) 16:330-6. doi:10.1111/j.1755-5949.2010.00182.x

33. Hanagasi HA, Gurvit H, Unsalan P, Horozoglu H, Tuncer N, Feyzioglu A, et al. The effects of rasagiline on cognitive deficits in Parkinson's disease patients without dementia: a randomized, double-blind, placebo-controlled, multicenter study. Mov Disord (2011) 26:1851-8. doi:10.1002/mds.23738

34. Dubois B, Tolosa E, Katzenschlager R, Emre M, Lees AJ, Schumann G, et al. Donepezil in Parkinson's disease dementia: a randomized, double-blind efficacy and safety study. Mov Disord (2012) 27:1230-8. doi:10.1002/mds.25098

35. Burn DJ, Rowan EN, Allan LM, Molloy S, O’Brien JT, Mckeith IG. Motor subtype and cognitive decline in Parkinson's disease, Parkinson's disease with dementia, and dementia with Lewy bodies. J Neurol Neurosurg Psychiatry (2006) 77:585-9. doi:10.1136/jnnp.2005.081711

36. Barone P, Scarzella L, Marconi R, Antonini A, Morgante L, Bracco F, et al Pramipexole versus sertraline in the treatment of depression in Parkinson's disease: a national multicenter parallel-group randomized study. J Neurol (2006) 253:601-7. doi:10.1007/s00415-006-0067-5

37. Pintor L, Bailles E, Valldeoriola F, Tolosa E, Marti MJ, De Pablo J. Response to 4-month treatment with reboxetine in Parkinson's disease patients with a major depressive episode. Gen Hosp Psychiatry (2006) 28:59-64. doi:10.1016/j. genhosppsych.2005.07.005 
38. Weintraub D, Taraborelli D, Morales KH, Duda JE, Katz IR, Stern MB. Escitalopram for major depression in Parkinson's disease: an open-label, flexibledosage study. J Neuropsychiatry Clin Neurosci (2006) 18:377-83. doi:10.1176/ appi.neuropsych.18.3.377

39. Devos D, Dujardin K, Poirot I, Moreau C, Cottencin O, Thomas P, et al. Comparison of desipramine and citalopram treatments for depression in Parkinson's disease: a double-blind, randomized, placebo-controlled study. Mov Disord (2008) 23:850-7. doi:10.1002/mds.21966

40. Palhagen SE, Carlsson M, Curman E, Walinder J, Granerus AK. Depressive illness in Parkinson's disease - indication of a more advanced and widespread neurodegenerative process? Acta Neurol Scand (2008) 117:295-304. doi:10.1111/j.1600-0404.2007.00986.x

41. Menza M, Dobkin RD, Marin H, Mark MH, Gara M, Buyske S, et al. The impact of treatment of depression on quality of life, disability and relapse in patients with Parkinson's disease. Mov Disord (2009) 24:1325-32. doi:10.1002/ mds. 22586

42. Palhagen S, Qi H, Martensson B, Walinder J, Granerus AK, Svenningsson P. Monoamines, BDNF, IL-6 and corticosterone in CSF in patients with Parkinson's disease and major depression. J Neurol (2010) 257:524-32. doi:10.1007/ s00415-009-5353-6

43. Dobkin RD, Menza M, Bienfait KL, Gara M, Marin H, Mark MH, et al. Depression in Parkinson's disease: symptom improvement and residual symptoms after acute pharmacologic management. Am J Geriatr Psychiatry (2011) 19:222-9. doi:10.1097/JGP.0b013e3181e448f7

44. Bonuccelli U, Meco G, Fabbrini G, Tessitore A, Pierantozzi M, Stocchi F, et al. A non-comparative assessment of tolerability and efficacy of duloxetine in the treatment of depressed patients with Parkinson's disease. Expert Opin Pharmacother (2012) 13:2269-80. doi:10.1517/14656566.2012.736490

45. Korchounov A, Winter Y, Rossy W. Combined beneficial effect of rasagiline on motor function and depression in de novo PD. Clin Neuropharmacol (2012) 35:121-4. doi:10.1097/WNF.0b013e31823b1da8

46. Mohs RC, Rosen WG, Davis KL. The Alzheimer's disease assessment scale: an instrument for assessing treatment efficacy. Psychopharmacol Bull (1983) 19:448-50.

47. Dujardin K, Devos D, Duhem S, Destee A, Marie RM, Durif F, et al. Utility of the Mattis dementia rating scale to assess the efficacy of rivastigmine in dementia associated with Parkinson's disease. J Neurol (2006) 253:1154-9. doi:10.1007/s00415-006-0175-2

48. Dubois B, Burn D, Goetz C, Aarsland D, Brown RG, Broe GA, et al. Diagnostic procedures for Parkinson's disease dementia: recommendations from the movement disorder society task force. Mov Disord (2007) 22:2314-24. doi:10.1002/mds.21844

49. Pagonabarraga J, Kulisevsky J, Llebaria G, Garcia-Sanchez C, Pascual-Sedano B, Martinez-Corral M, et al. PDD-short screen: a brief cognitive test for screening dementia in Parkinson's disease. Mov Disord (2010) 25:440-6. doi:10.1002/mds. 22877

50. Kalbe E, Calabrese P, Kohn N, Hilker R, Riedel O, Wittchen HU, et al. Screening for cognitive deficits in Parkinson's disease with the Parkinson neuropsychometric dementia assessment (PANDA) instrument. Parkinsonism Relat Disord (2008) 14:93-101. doi:10.1016/j.parkreldis.2007.06.008

51. Mahieux F, Michelet D, Manifacier MJ, Boller F, Fermanian J, Guillard A. Mini-mental Parkinson: first validation study of a new bedside test constructed for Parkinson's disease. Behav Neurol (1995) 8:15-22. doi:10.3233/ BEN-1995-8102
52. Marinus J, Visser M, Verwey NA, Verhey FR, Middelkoop HA, Stiggelbout AM, et al. Assessment of cognition in Parkinson's disease. Neurology (2003) 61:1222-8. doi:10.1212/01.WNL.0000091864.39702.1C

53. Pagonabarraga J, Kulisevsky J, Llebaria G, Garcia-Sanchez C, Pascual-Sedano B, Gironell A. Parkinson's disease-cognitive rating scale: a new cognitive scale specific for Parkinson's disease. Mov Disord (2008) 23:998-1005. doi:10.1002/ mds. 22007

54. Kulisevsky J, Pagonabarraga J, Pascual-Sedano B, Garcia-Sanchez C, Gironell A, Trapecio Group S. Prevalence and correlates of neuropsychiatric symptoms in Parkinson's disease without dementia. Mov Disord (2008) 23:1889-96. doi: $10.1002 / \mathrm{mds} .22246$

55. Butterfield LC, Cimino CR, Oelke LE, Hauser RA, Sanchez-Ramos J. The independent influence of apathy and depression on cognitive functioning in Parkinson's disease. Neuropsychology (2010) 24:721-30. doi:10.1037/a0019650

56. Bohnen NI, Kaufer DI, Hendrickson R, Constantine GM, Mathis CA, Moore RY. Cortical cholinergic denervation is associated with depressive symptoms in Parkinson's disease and parkinsonian dementia. J Neurol Neurosurg Psychiatry (2007) 78:641-3. doi:10.1136/jnnp.2006.100073

57. Meyer PM, Strecker K, Kendziorra K, Becker G, Hesse S, Woelpl D, et al. Reduced alpha4beta $2^{*}$-nicotinic acetylcholine receptor binding and its relationship to mild cognitive and depressive symptoms in Parkinson disease. Arch Gen Psychiatry (2009) 66:866-77. doi:10.1001/archgenpsychiatry.2009.106

58. Alves G, Larsen JP, Emre M, Wentzel-Larsen T, Aarsland D. Changes in motor subtype and risk for incident dementia in Parkinson's disease. Mov Disord (2006) 21:1123-30. doi:10.1002/mds.20897

59. Tremblay C, Achim AM, Macoir J, Monetta L. The heterogeneity of cognitive symptoms in Parkinson's disease: a meta-analysis. J Neurol Neurosurg Psychiatry (2013) 84:1265-72. doi:10.1136/jnnp-2013-305021

60. Rolinski M, Fox C, Maidment I, Mcshane R. Cholinesterase inhibitors for dementia with Lewy bodies, Parkinson's disease dementia and cognitive impairment in Parkinson's disease. Cochrane Database Syst Rev (2012) 3:CD006504. doi:10.1002/14651858.CD006504.pub2

61. Pae CU. Comments on 'what is a rational antidepressant treatment for major depression in patients with Parkinson's disease?. Psychiatry Clin Neurosci (2013) 67:65-6. doi:10.1111/pcn.12009

Conflict of Interest Statement: The authors declare that the research was conducted in the absence of any commercial or financial relationships that could be construed as a potential conflict of interest.

Received: 31 October 2014; accepted: 16 March 2015; published online: 31 March 2015. Citation: Sandoval-Rincón M, Sáenz-Farret M, Miguel-Puga A, Micheli F and AriasCarrión $O$ (2015) Rational pharmacological approaches for cognitive dysfunction and depression in Parkinson's disease. Front. Neurol. 6:71. doi: 10.3389/fneur.2015.00071 This article was submitted to Movement Disorders, a section of the journal Frontiers in Neurology.

Copyright (C) 2015 Sandoval-Rincón, Sáenz-Farret, Miguel-Puga, Micheli and AriasCarrion. This is an open-access article distributed under the terms of the Creative Commons Attribution License (CC BY). The use, distribution or reproduction in other forums is permitted, provided the original author(s) or licensor are credited and that the original publication in this journal is cited, in accordance with accepted academic practice. No use, distribution or reproduction is permitted which does not comply with these terms. 